\title{
EFFECTS OF OESTROGEN, ADMINISTERED EARLY OR LATE IN THE OESTROUS CYCLE, UPON THE SURVIVAL AND REGRESSION OF THE CORPUS LUTEUM OF THE GUINEA-PIG
}

\author{
DOREEN V. ILLINGWORTH AND J. S. PERRY \\ A.R.C. Institute of Animal Physiology, Babraham, Cambridge
}

(Received 17th May 1972)

\begin{abstract}
Summary. The lytic effect of oestrogen administered within the first 5 days of ovulation in the guinea-pig can be abolished by hysterectomy and is greatly reduced by hypophysectomy. After Day 9 of the cycle, large doses of oestrogen resulted in the maintenance of the CL for at least 3 weeks after ovulation, and in many instances for more than 4 weeks, and their further growth to sizes seen after hysterectomy or during pregnancy $\left(3 \cdot 2 \pm 0.3 \mathrm{~mm}^{3}\right)$. These large $\mathrm{CL}$ contained and secreted more progesterone than those of the normal cycle. Hypophysectomy did not abolish the antiluteolytic effect of oestrogen. A luteotrophic, not solely an antiluteolytic, effect of the hormone could be demonstrated. The luteolytic or luteotrophic action of oestrogen did not depend upon the age of the CL but upon pituitary and/or uterine factors. The study used mainly stilboestrol, but similar results were obtained with oestradiol compounds.
\end{abstract}

\section{INTRODUCTION}

Exogenous oestrogen, administered to guinea-pigs within the first 4 days of the cycle, caused the premature regression of the CL (Choudary \& Greenwald, 1968). This lytic effect of oestrogen could be abolished by hysterectomy (Bland \& Donovan, 1968) or hypophysectomy (Illingworth, 1969) or FSH treatment (Choudary \& Greenwald, 1969). Two contrasting mechanisms of oestrogen action have been proposed: activation of the uterine luteolytic factor (Bland \& Donovan, 1970) or inhibition of essential luteotrophin secretion (Choudary \& Greenwald, 1969).

In a preliminary investigation, Illingworth (1969) showed that oestrogen administered late in the cycle was not lytic, and prevented the regression of the CL. This luteotrophic effect has been reported in several species, e.g. rat (Nelson, 1935) and pig (Nishikawa \& Waide, 1958). In the guinea-pig, the CL continued to grow, reaching sizes seen after hysterectomy or during pregnancy. This antiluteolytic and/or luteotrophic effect of oestrogen late in the cycle was not abolished by hypophysectomy.

The results reported in this paper are an extension of this work, in an attempt to answer the following questions: (1) the preliminary investigation used stil- 
boestrol; can the results be repeated using other oestrogens; (2) can the two opposing theories of the mechanism of oestrogen-induced lysis be reconciled; (3) are any pituitary factors involved in the maintenance and further growth of the CL; (4) is the action of oestrogen in preventing the regression of the CL solely antiluteolytic, or could a positive luteotrophic component be demonstrated; (5) for how long can the CL be maintained and can they survive for a significant time after the removal of the stilboestrol tablets; $(6)$ do the two very different effects of oestrogen, regression or maintenance, depend upon the age of the $\mathrm{CL}$, or upon other factors, perhaps pituitary or uterine in origin?

\section{MATERIALS AND METHODS}

\section{Animals}

The guinea-pigs were from the Institute's own colony of mixed stock; most were virgin animals. They were examined daily for vaginal opening for at least two cycles before use. The day of full vaginal opening (oestrus) was designated Day 0 . When experimental procedures were carried out within 5 days of ovulation, vaginal smears were taken during vaginal opening. The first postovulatory influx of leucocytes determined Day 1.

\section{Operative procedures}

Ether anaesthesia, following preliminary Avertin sedation, was used for most surgical procedures. Tribromoethanol (Avertin, Bayer-Winthrop Ltd) was made up as $0.5 \mathrm{ml}$ Avertin $+2 \mathrm{ml}$ ethanol $+25 \mathrm{ml}$ sterile $0.9 \%$ saline and administered intraperitoneally at the dose of $1 \mathrm{ml} / 100 \mathrm{~g}$ body weight. For hypophysectomy, halothane was preferred to ether.

The ovaries were examined by double flank incisions, and hysterectomy was performed through a single mid-ventral abdominal incision. Hypophysectomy was performed by the parapharyngeal route (McPhail \& Parkes, 1933). Following surgery, hypophysectomized animals were maintained at temperatures between 21 and $28^{\circ} \mathrm{C}$ and were given daily injections of $12.5 \mathrm{mg}$ cortisone acetate (Cortistab, Boots Ltd). Completeness of hypophysectomy was assessed at death either by examining the sella turcica or from serial sections of the hypothalamo-hypophysial region.

\section{Histology}

At autopsy, the reproductive organs were removed, fixed overnight in Bouin's fluid, dehydrated and embedded in paraffin wax. Serial $(7-\mu \mathrm{m})$ sections were cut and every tenth ovarian section and representative sections of the uterus and vagina were mounted and stained with Erlich's haematoxylin and eosin. Luteal volume was calculated by the method of Rowlands (1961).

\section{Plasma and luteal progesterone}

Most of the experiments were performed before the simple protein-binding assay for progesterone came into use in our laboratory, thus plasma and CL were collected only in later experiments. Blood was withdrawn into heparinized syringes by cardiac puncture under light Nembutal anaesthesia before the 
animal was killed. It was centrifuged immediately and stored at $-15^{\circ} \mathrm{C}$ until analysis. Corpora lutea were dissected out quickly onto ice and stored frozen at $-15^{\circ} \mathrm{C}$ until analysis. The analysis of progesterone in the plasma and CL has been described previously (Illingworth \& Perry, 1971; Challis, Heap \& Illingworth, 1971).

\section{Metabolic clearance rate of progesterone}

The metabolic clearance rate was measured in three stilboestrol-treated guinea-pigs. These animals had $3 \times 25 \mathrm{mg}$ stilboestrol tablets implanted on Day 11 of the cycle. Absorption from this amount of hormone is sufficient to maintain the CL. The metabolic clearance rate was measured 10 or 11 days later, using the continuous infusion technique previously described in detail (Illingworth, Heap \& Perry, 1970).

\section{Hormones}

All tablets were implanted subcutaneously between the shoulder blades. After removal, the tablets were wiped clean and oven-dried to a constant weight. The daily absorption rate could then be calculated.

Diethyl stilboestrol. As (a) 25-mg implants (Organon); (b) tablets of different weights made in this laboratory from the pure solid (Burrough's Wellcome).

Oestradiol. Sterile 10-mg implants (Organon).

Oestradiol propionate. Approximately $10-\mathrm{mg}$ implants of pure solid.

Oestradiol cypionate. Oestradiol cyclopentyl propionate (ECP) was dissolved in arachis oil to give an injection volume of $0.2 \mathrm{ml} ; 50 \mu \mathrm{g}$ were injected, as a single injection.

\section{Design of experiments}

The doses of oestrogen used, the time of administration, and the condition of the animals are shown in Table 1. In later experiments, other oestrogens (ECP, oestradiol propionate, oestradiol) were used in place of stilboestrol to check that the results were due to the action of oestrogens in general and were not peculiar to stilboestrol. Two experiments, omitted from Table 1 because of the difficulty of tabulating them, are described in more detail below.

Experiment 1. An attempt was made to determine the persistence of the luteotrophic influence of oestrogen after removal of the tablets. Stilboestrol tablets $(3 \times 25 \mathrm{mg})$ were implanted on Days 9 to 13 ; one ovary and the tablets were removed on Days 19 to 22 , and the remaining ovary was checked for the presence of large CL. The animals were killed 5 to 12 days later and the remaining ovary was removed.

Experiment 2. Since oestrogen was found to have two such opposite reactions depending on the time of administration, the effect of oestrogen was examined when two 'sets' of CL, of different ages, were present in the same ovary. A single injection of LH $(100 \mu \mathrm{g})$ on Day 8 induced the formation of additional CL (or pseudo-CL) by the luteinization of some of the large antral follicles. On Day 11 or 12, at the time of oestrogen implantation, some CL were of an age when they were normally lysed by oestrogen treatment, and others of an age when they were normally maintained by oestrogen. 
Table 1. Experiments undertaken with oestrogen. Details of surgical treatment of guinea-pigs, dosage of oestrogen and time of administration

\begin{tabular}{|c|c|c|c|c|c|}
\hline Treatment & Hormone & $\begin{array}{c}\text { No. of } \\
\text { animals }\end{array}$ & Dose & $\begin{array}{l}\text { Day of opera- } \\
\text { tion and } \\
\text { hormone } \\
\text { administration }\end{array}$ & $\begin{array}{l}\text { Day of } \\
\text { autopsy }\end{array}$ \\
\hline \multirow{2}{*}{$\begin{array}{l}\text { Before Day } 5 \text { of the } \\
\text { cycle } \\
\text { Intact }\end{array}$} & & & & & \\
\hline & $\begin{array}{l}\text { Stilboestrol } \\
\text { EGP } \\
\text { Oestradiol } \\
\text { propionate }\end{array}$ & $\begin{array}{l}3 \\
2 \\
1\end{array}$ & $\begin{array}{l}25 \mathrm{mg} \\
50 \mu \mathrm{g} \text { (inj.) } \\
10 \mathrm{mg}\end{array}$ & $\begin{array}{l}4 \\
2 \text { to } 4 \\
4\end{array}$ & $\begin{array}{l}15 \text { to } 16 \\
11 \\
11\end{array}$ \\
\hline Hysterectomy & $\begin{array}{l}\text { Stilboestrol } \\
\text { EGP }\end{array}$ & $\begin{array}{l}7 \\
1\end{array}$ & $\begin{array}{l}25 \text { to } 75 \mathrm{mg} \\
50 \mu \mathrm{g}\end{array}$ & $\begin{array}{l}2 \text { to } 5 \\
4\end{array}$ & $\begin{array}{l}11 \text { to } 16 \\
18\end{array}$ \\
\hline $\begin{array}{l}\text { Hemi- } \\
\text { hysterectomy }\end{array}$ & EGP & 4 & $50 \mu \mathrm{g}$ & 2 & 11 \\
\hline Hypophysectomy & $\begin{array}{l}\text { Stilboestrol } \\
\text { ECP } \\
\text { Oestradiol } \\
\text { propionate }\end{array}$ & $\begin{array}{l}5 \\
5 \\
1\end{array}$ & $\begin{array}{l}25 \text { to } 75 \mathrm{mg} \\
50 \mu \mathrm{g} \\
10 \mathrm{mg}\end{array}$ & $\begin{array}{l}2 \text { to } 4 \\
2 \text { to } 4 \\
3\end{array}$ & $\begin{array}{l}9 \text { to } 15 \\
11 \text { to } 15 \\
11\end{array}$ \\
\hline \multirow{2}{*}{$\begin{array}{l}\text { On and after Day } 9 \\
\text { of the cycle } \\
\text { Intact }\end{array}$} & & & & & \\
\hline & $\begin{array}{l}\text { Stilboestrol } \\
\text { Oestradiol }\end{array}$ & $\begin{array}{r}21 \\
4\end{array}$ & $\begin{array}{l}18 \cdot 6 \text { to } 125 \mathrm{mg} \\
10 \mathrm{mg}\end{array}$ & $\begin{array}{r}9 \text { to } 13 \\
10 \text { to } 11\end{array}$ & $\begin{array}{l}19 \text { to } 27 \\
17 \text { to } 24\end{array}$ \\
\hline Hypophysectomy & $\begin{array}{l}\text { Stilboestrol } \\
\text { Oestradiol }\end{array}$ & $\begin{array}{r}10 \\
2\end{array}$ & $\begin{array}{l}22 \text { to } 124 \mathrm{mg} \\
20 \mathrm{mg}\end{array}$ & $\begin{array}{r}9 \text { to } 13 \\
11 \text { to } 12\end{array}$ & $\begin{array}{l}17 \text { to } 22 \\
17 \text { to } 19\end{array}$ \\
\hline Hysterectomy & $\begin{array}{l}\text { Control } \\
\text { Stilboestrol } \\
\text { Oestradiol }\end{array}$ & $\begin{array}{l}6 \\
6 \\
1\end{array}$ & $\begin{array}{l}75 \text { to } 97 \mathrm{mg} \\
10 \mathrm{mg}\end{array}$ & $\begin{array}{l}13 \text { to } 14 \\
13 \text { to } 14 \\
13\end{array}$ & $\begin{array}{l}20 \text { to } 21 \\
20 \text { to } 22 \\
24\end{array}$ \\
\hline
\end{tabular}

\section{RESULTS}

The term 'luteolytic' is here used in the sense of 'causing the CL to regress and to cease secreting progesterone' and 'luteotrophic' is used as 'causing an increase in size and/or secretory activity of the CL'. By 'antiluteolytic' is meant 'preventing the structural or functional regression of the CL without increasing its size or secretory activity'.

Oestrogen administered early in the cycle

As shown by others (Choudary \& Greenwald, 1968; Bland \& Donovan, 1968, 1970), oestrogen administered before Day 5 of the cycle caused the premature regression of the CL. After hysterectomy (Bland \& Donovan, 1968) or hemihysterectomy, this luteolytic effect was abolished in the ovary on the side of the horn which had been removed (Bland \& Donovan, 1970). Oestrogen had no initial luteotrophic effect in the oestrogen-treated hysterectomized animals (Table 2). Luteal size, progesterone content and plasma progesterone levels were within the expected limits for untreated hysterectomized animals at a similar time after ovulation. The results obtained with stilboestrol, ECP and oestradiol propionate confirmed the work of the other groups and the earlier study using stilboestrol (Illingworth, 1969).

After oestrogen treatment, most of the Graafian follicles showed marked degeneration of the granulosa-cell layer, even after a single injection of EGP. 
Choudary \& Greenwald (1968) also noted this effect but reported further ovulations in a few animals given low doses of the hormone. One of the two animals given ECP in these experiments, but none of the three stilboestroltreated animals, ovulated again.

Hypophysectomy also greatly reduced the lytic effect of oestrogen. Regressed CL were seen in only one animal, receiving ECP. The CL of the remaining animals closely resembled those of hypophysectomized untreated animals, with small densely packed cells (Perry \& Rowlands, 1962; Heap, Perry \& Rowlands, 1967). Their size varied considerably (from 1.85 to $0.7 \mathrm{~mm}^{3}$ ) and the mean volume $\left(1 \cdot 2 \pm 0 \cdot 1 \mathrm{~mm}^{3}, n=32\right)$ was slightly lower than would be expected for comparable hypophysectomized animals $(1 \cdot 49 \pm 0 \cdot 12$; Heap et al., 1967). Although the GL showed no sign of structural luteolysis in spite of their small size, the plasma progesterone levels measured in two animals $(1.2$ and $0.25 \mathrm{ng} / \mathrm{ml})$ indicated that they were much less functionally active than those of untreated

Table 2. The effect of oestrogen administered to guinea-pigs early in the cycle

\begin{tabular}{|c|c|c|c|c|c|c|}
\hline Group & $\begin{array}{c}\text { Luteal volume } \\
\left(\mathrm{mm}^{3}\right) \\
(\text { mean } \pm \text { S.E. })\end{array}$ & $\begin{array}{c}\text { No. } \\
\text { of } \\
\text { animals }\end{array}$ & $\begin{array}{c}\text { Plasma } \\
\text { progesterone } \\
(\text { ng/ml })\end{array}$ & $\begin{array}{c}\text { No. } \\
\text { of } \\
\text { animals }\end{array}$ & $\begin{array}{c}\text { Luteal } \\
\text { progesterone } \\
\text { (ng/mg) }\end{array}$ & $\begin{array}{c}\text { No. } \\
\text { of } \\
\text { animals }\end{array}$ \\
\hline Normal (mid-cycle) & $2 \cdot 00 \pm 0 \cdot 05^{*}$ & 6 & $2 \cdot 5 \pm 0 \cdot 2$ & $34 \dagger$ & $7 \cdot 6 *$ & 4 \\
\hline Oestrogen-treated & $0.22 \pm 0.02$ & 6 & - & - & - & - \\
\hline $\begin{array}{l}\text { Oestrogen-treated, } \\
\text { hysterectomized }\end{array}$ & $2 \cdot 2 \pm 0 \cdot 3$ & 8 & $3 \cdot 0 \pm 0 \cdot 2$ & 4 & $16 \pm 4$ & 3 \\
\hline $\begin{array}{l}\text { Oestrogen-treated, } \\
\text { hemihysterectomized }\end{array}$ & $2 \cdot 08 \pm 0.3$ & 4 & - & - & - & - \\
\hline Hypophysectomized & $1 \cdot 49 \pm 0 \cdot 12^{*}$ & 12 & $2 \cdot 2 \pm 0 \cdot 3$ & 4 & $32 *$ & 12 \\
\hline $\begin{array}{l}\text { Hypophysectomized, } \\
\text { oestrogen-treated }\end{array}$ & $1 \cdot 20 \pm 0.07$ & 10 & $1 \cdot 2,0 \cdot 25$ & 2 & - & 一 \\
\hline
\end{tabular}

* Data from Heap et al. (1967).

$\uparrow$ Data from Challis et al. (1971).

hypophysectomized animals. Plasma progesterone concentrations and production rates in untreated hypophysectomized animals were indistinguishable from those of normal intact guinea-pigs during the luteal phase of the oestrous cycle (Illingworth \& Perry, 1971; Illingworth, 1971).

\section{Oestrogen administered late in the cycle}

In most of the animals, oestrogen implanted from Days 9 to 13 not only prevented the regression of the CL, but also resulted in their further growth to sizes sometimes even larger than those seen during pregnancy or after hysterectomy. They were well vascularized, with large cells containing rounded nuclei and abundant eosinophilic cytoplasm; many mitotic figures were present. The CL, especially after Day 22, tended to lose their spherical form and become more irregular in outline.

Luteinization of some follicles occurred, but never to the extent of forming additional 'induced' or pseudo-CL, as after LH injection. In many of the 
Graafian follicles, the granulosa-cell layer contained degenerating cells, but in others, as in most of the small follicles, no changes were observed. It was noticeable that, in many animals, the theca interna seemed to consist of more cell layers than were seen in either a normal pregnant or a non-pregnant animal. This thickening was more apparent when stilboestrol rather than oestradiol compounds were used.

Hypophysectomy at the time of hormone implantation did not abolish the antiluteolytic effect of oestrogen; hypophysectomy at this stage of the cycle does not prevent luteal regression in untreated animals (Perry \& Rowlands, 1962; Heap et al., 1967). The CL of the hypophysectomized oestrogen-treated animals were smaller than those of the intact stilboestrol-treated animals (Table 3 ). The absorption rates of oestrogen in the hypophysectomized animals tended to be lower than in the intact animals. The plasma and luteal progesterone levels indicated the variable functional state of the CL.

Table 3. The effect of oestrogen administered to guinea-pigs late in the cycle

\begin{tabular}{c|cc|cc|cc}
\hline Group & $\begin{array}{c}\text { Vol. of CL } \\
\left(\mathrm{mm}^{3}\right) \\
(\text { mean } \pm \text { S.E. })\end{array}$ & $\begin{array}{c}\text { No. } \\
\text { of } \\
\text { CL }\end{array}$ & $\begin{array}{c}\text { Plasma } \\
\text { progesterone } \\
(\mathrm{ng} / \mathrm{ml}) \\
(\text { mean } \pm S . E .)\end{array}$ & $\begin{array}{c}\text { No. } \\
\text { of } \\
\text { animals }\end{array}$ & $\begin{array}{c}\text { Luteal } \\
\text { progesterone } \\
(\mathrm{ng} / \mathrm{mg}) \\
(\text { mean } \pm S . E .)\end{array}$ & $\begin{array}{c}\text { No. } \\
\text { of } \\
\text { animals }\end{array}$ \\
\hline $\begin{array}{c}\text { Hysterectomized 20 } \\
\text { days after ovulation }\end{array}$ & $2.88 \pm 0.08^{*}$ & 32 & $3.9 \pm 0.3$ & 3 & $53.1 \dagger$ & 3 \\
$\begin{array}{c}\text { Pregnant, 20 days after } \\
\text { ovulation }\end{array}$ & $3 \mathrm{~mm}^{*}$ & & 113.6 & 4 & $28.8 \dagger$ & 4 \\
$\begin{array}{c}\text { Intact, oestrogen- } \\
\text { treated }\end{array}$ & $3.2 \pm 0.3$ & 53 & $3.5 \pm 0.5$ & 4 & $21.2 \pm 3.1$ & 4 \\
$\begin{array}{c}\text { Hypophysectomized, } \\
\text { oestrogen-treated }\end{array}$ & $1.89 \pm 0.2$ & 27 & $2.4 \pm 0.7$ & 4 & $20.6 \pm 3.8$ & 3 \\
$\begin{array}{c}\text { Hypophysectomized, } \\
\text { untreated }\end{array}$ & $1.43 \pm 0.2 \dagger$ & $8 \ddagger$ & 3.0 & 2 & 33 & $18 \dagger$ \\
\hline
\end{tabular}

* Data from Rowlands (1961).

$\dagger$ Data from Heap et al. (1967).

¥No. of animals quoted, not no. of CL.

Maintenance of luteal structure and function depended upon the dose absorbed. Less than $0.5 \mathrm{mg} /$ day absorbed from the stilboestrol implants was insufficient to prevent luteal regression. Absorption from the oestradiol implants was much lower; often less than $1 \mathrm{mg}$ was absorbed over the experimental period. These low absorption rates could not be calculated accurately. Some signs of oestrogen toxicity (weight loss, slight hair loss) were observed in animals absorbing the very high doses of stilboestrol, i.e. quantities exceeding 1.0 to 1.5 $\mathrm{mg} /$ day. Six different schedules of ECP injection were tried, from $100 \mu \mathrm{g}$ by a single injection on Day 11, to $50 \mu \mathrm{g} /$ day from Days 11 to 16 , but failed to prevent the regression of the CL at the normal time.

The luteotrophic effect of oestrogen in addition to its antiluteolytic effect is also demonstrated by comparing the results of hysterectomy performed on Day 13 or 14 of the cycle with hysterectomy+oestrogen treatment at this late 
stage. In one of the six untreated animals hysterectomized on Day 13, the CL grew as large (average vol. $=4.2 \mathrm{~mm}^{3} ; n=2$ ) as those seen after hysterectomy early in the cycle. The CL of the other five animals were small $\left(1.5 \pm 0.02 \mathrm{~mm}^{3}\right.$, $n=11$ ). Those from seven oestrogen-treated hysterectomized animals showed considerable variation in size (as in oestrogen-treated intact animals) but the average volume $\left(2 \cdot 4 \pm 0 \cdot 2 \mathrm{~mm}^{3}, n=23\right)$ was significantly larger than that in the untreated hysterectomized animals at an equivalent stage after ovulation $(P<0.05)$. Progesterone concentrations in plasma and luteal tissue, which were measured in a further two oestrogen-treated hysterectomized animals, also reflected the wide range of results obtained after oestrogen treatment of intact animals. In one, the plasma level was $2.8 \mathrm{ng} / \mathrm{ml}$ and the tissue concentration was $5.9 \mathrm{ng} / \mathrm{mg}$. Although this plasma progesterone level is similar to mid-Iuteal concentrations in normal animals, the luteal progesterone is somewhat lower (Rowlands \& Short, 1959; Heap et al., 1967; Feder, Resko \& Goy, 1968; Challis et al., 1971). The other animal had a very high plasma progesterone $(8.9 \mathrm{ng} / \mathrm{ml})$ and a high luteal concentration $(25 \mathrm{ng} / \mathrm{mg})$, similar to some values in intact oestrogen-treated animals (Tables 3 and 4).

Table 4. Volumes of CL, and plasma progesterone levels, in stilboestroltreated guinea-pigs

\begin{tabular}{|c|c|c|c|c|c|}
\hline \multirow{2}{*}{$\begin{array}{c}\text { Animal } \\
\text { no. }\end{array}$} & \multirow{2}{*}{$\begin{array}{c}\text { Interval (days) } \\
\text { from } \\
\text { Day } A \text { to Day } B\end{array}$} & \multicolumn{2}{|c|}{ Av. vol. of $C L\left(\mathrm{~mm}^{3}\right)$ and no. } & \multicolumn{2}{|c|}{ Plasma progesterone $(\mathrm{ng} / \mathrm{ml})$} \\
\hline & & Ovary $A$ & Ovary $B$ & Day $A$ & Day $B$ \\
\hline $\begin{array}{l}1 \\
2 \\
3 \\
4 \\
5 \\
6\end{array}$ & $\begin{array}{r}12 \\
7 \\
5 \\
8 \\
7 \\
7\end{array}$ & $\begin{array}{ll}1 \cdot 7 & 2 \\
2 \cdot 7 & 3 \\
3 \cdot 3 & 3 \\
3 \cdot 7 & 1 \\
3 \cdot 6 & 3 \\
3 \cdot 7 & 1\end{array}$ & $\begin{array}{ll}0.5 & 1 \\
1.9 & 1 \\
0.2 & 3 \\
5.3 & 2 \\
3.7 & 1 \\
3.2 & 2\end{array}$ & $\begin{array}{l}- \\
\overline{4} \cdot 8 \\
5 \cdot 3 \\
5 \cdot 6 \\
5 \cdot 1\end{array}$ & $\begin{array}{l}- \\
0 \cdot 0 \\
5 \cdot 3 \\
1 \cdot 9 \\
3 \cdot 9\end{array}$ \\
\hline
\end{tabular}

Day A: Ovary A and stilboestrol tablets removed. Day B: Animal killed; Ovary B removed.

Oestrogen implanted at this late stage of the cycle did cause the complete luteinization of some follicles to form small pseudo-CL, but these were readily distinguishable from the CL of the oestrous cycle, and have not been included in the calculation of mean luteal volume.

Corpora lutea sometimes persisted after removal of stilboestrol tablets (Table 4). In two of the six animals, regression had occurred between the time of tablet removal and autopsy. In one of these animals, the CL of the first ovary were smaller than expected. In the last three animals, the CL were still large and were secreting progesterone 7 to 8 days after the stilboestrol implants were removed.

When oestrogen was given to guinea-pigs with two 'sets' of CL (see Exp. 2, 'Materials and Methods' section), in four out of six animals both the LHinduced and the original CL were maintained. In the remaining two animals, insufficient oestrogen was absorbed to counteract the luteolytic effect of the uterus. The two 'sets' of maintained GL were very similar in size and in the 
appearance of the lutein cells. The mean luteal volume of both sets was $2 \cdot 8 \pm 0 \cdot 5$ $\mathrm{mm}^{3}(n=19)$. Measurements of luteal progesterone in another animal (in which 'induced' GL had been seen in both ovaries at the time when tablets were implanted) showed that luteal progesterone concentrations were similar in both the 'induced' and cyclic CL, about $25 \mathrm{ng} / \mathrm{mg}$. The plasma progesterone concentration in this animal was $7 \cdot 0 \mathrm{ng} / \mathrm{ml}$.

The metabolic clearance rate of progesterone was measured in three animals 12 days after stilboestrol tablets had been implanted on Day 10 or 11 of the cycle. When examined after the infusion experiments, the ovaries of the three animals contained the large CL typical of oestrogen-treated animals. The metabolic clearance rate $(144 \pm 3.31 / \mathrm{day} / \mathrm{kg})$ was at the high rate typical of the non-pregnant animal $(112 \pm 7.01 /$ day $/ \mathrm{kg}$; Illingworth et al., 1970). The production rate of progesterone, calculated from the metabolic clearance rate and plasma concentration, was almost $0.6 \mathrm{mg} / \mathrm{day} / \mathrm{kg}$. This is higher than the calculated peak value of the luteal phase of the oestrous cycle $(0.24 \mathrm{mg} /$ day; Challis et al., 1971), but is about half that of the pregnant animal (1.24 mg/day). Although plasma progesterone concentrations were similar in hysterectomized and oestrogen-treated animals (Table 3 ), luteal progesterone concentrations in the oestrogen-treated animals were about $50 \%$ of those in hysterectomized animals. The calculated production rate of $0.6 \mathrm{mg} /$ day in oestrogen-treated animals, however, is very similar to that of hysterectomized animals (D. V. Illingworth, unpublished observation).

\section{DISCUSSION}

The oestrogens administered early in the cycle (stilboestrol, ECP, oestradiol propionate) at the doses used (see Table 1) gave very similar results. The lytic effect of stilboestrol was obtained with smaller doses $(<0.5 \mathrm{mg} /$ day absorbed) than the antiluteolytic effect later in the cycle, which required an absorption of $>0.5 \mathrm{mg} /$ day. This antiluteolytic effect could also be obtained using oestradiol implants. Oestradiol was more potent than stilboestrol in preventing the regression of the CL; absorption of less than $100 \mu \mathrm{g} /$ day of oestradiol was sufficient to overcome the lytic effect of the uterus. Too few experiments have been performed to construct an accurate dose/response curve for stilboestrol, but the larger CL were associated with the higher absorption rates.

Since the precocious luteolysis induced by oestrogen administered early in the cycle can be totally prevented by hysterectomy, this effect must depend on its stimulating the uterine luteolytic mechanism directly or indirectly. The local protection afforded by hemihysterectomy against the lytic action of oestrogen (Bland \& Donovan, 1970) is additional evidence in support of this hypothesis. It has also been shown that oestrogen given early in the cycle results in high levels of prostaglandin- $\mathrm{F}_{2 \alpha}$ in utero-ovarian venous blood (Blatchley, Donovan, Poyser, Horton, Thompson \& Los, 1971), and $\mathrm{PGF}_{2 \alpha}$ is known to exert a luteolytic effect in the guinea-pig (Blatchley \& Donovan, 1969). Choudary \& Greenwald (1969), on the other hand, claimed that this action of oestrogen is antiluteotrophic, since they found that FSH (but not LH and/or prolactin) abolished the oestrogen-induced luteolysis. They also suggested that in the 
guinea-pig, as in the hamster (Greenwald, 1967), FSH is necessary for the normal development of the CL, and suggested that oestrogen causes luteolysis by inhibiting the pituitary secretion of FSH. The guinea-pig CL, however, is not entirely dependent upon pituitary luteotrophins for its continued growth and function. Heap et al. (1967) reported that hypophysectomy 2 days after ovulation did not prevent further luteal growth, and subsequent experiments (D. V. Illingworth, unpublished observations) have indicated that hypophysectomy, even within $24 \mathrm{hr}$ of ovulation, will also allow luteal development. Another argument against the luteotrophin requirement for FSH, as Bland \& Donovan (1970) point out, is the local effect of hemihysterectomy.

The oestrogen-induced regression was extensively reduced by hypophysectomy, but the deleterious effects of oestrogen were still evident. The CL were not as large as they would have been after hypophysectomy alone (Heap et al., 1967). It would seem reasonable to conjecture that although hypophysectomy had hindered the rapid lytic effect of oestrogen, the CL would regress soon after Day 15, and would not be maintained for as long as CL in untreated hypophysectomized animals. Pituitary hormones are involved in the normal regulation of the guinea-pig luteolytic mechanism, for after either hypophysectomy (Perry \& Rowlands, 1962; Heap et al., 1967) or pituitary stalk-section (Illingworth \& Perry, 1971), the CL continue to grow and secrete progesterone for at least 3 weeks and possibly more than 5 weeks after ovulation, in spite of the continued presence of the uterus. Perhaps FSH protects against the lytic action of oestrogen by opposing the pituitary component of the lytic mechanism.

By contrast, a large dose of oestrogen administered much later in the cycle is both antiluteolytic and positively luteotrophic. The dose of oestrogen required is much in excess of estimated physiological levels, and the effect is probably pharmacological and unrelated to the antiluteolytic and luteotrophic action of the conceptus. Oestrogen abolishes the lytic action of the uterus, and the CL continue to grow; they contain and secrete large quantities of progesterone. It is not clear whether the antiluteolytic action is at uterine or ovarian level, or whether the luteotrophic effect involves pituitary factors. Although the oestrogen-treated hypophysectomized animals had smaller $\mathbf{C L}$, the difference in size might be accounted for by the slightly lower absorption rates.

The luteotrophic action of oestrogen is clearly shown in the experiments in which the guinea-pigs were hysterectomized late in the cycle. Although this operation prevents the complete regression of the CL, they do not normally reach the large sizes associated with hysterectomy performed earlier in the cycle (Rowlands, 1961). After oestrogen treatment, the CL of the animals hysterectomized late in the cycle did grow, but whether this is a direct effect of oestrogen on the lutein cells or is pituitary-mediated is, again, not known.

Exogenous oestrogens have been shown to prolong the life and function of the CL in the pig (Nishikawa \& Waide, 1958; Gardner, First \& Casida, 1963), sheep (Denamur \& Mauléon, 1963; Piper \& Foote, 1965), pseudopregnant rabbit (Chu, Lee \& You, 1945) and rat (Nelson, 1935). In the pig, oestrogen injections from Days 12 to 19 are sufficient to maintain the CL for a time comparable to their persistence after hysterectomy or in pregnancy (Nishikawa \& 
Waide, 1958; du Mesnil du Buisson, 1967) and in the sheep, oestrogen for a similar period will maintain the CL for at least 37 days (Piper \& Foote, 1965, 1970). Similarly, our results in the guinea-pig (Table 4) indicate that CL maintained by oestrogen implants from Days 11 to 22 may persist for some time after the removal of the tablets. The degree of maintenance was variable and seemed to depend upon the condition of the CL at Day 22. We have not investigated in detail the length of time that stilboestrol will maintain luteal function, but blood samples taken at 5-day intervals from a guinea-pig with stilboestrol implants showed that functional luteal activity in this animal was maintained by oestrogen for at least 40 days after ovulation.

Small doses of oestrogen late in the cycle can hasten the regression of the CL of the sheep (Stormshak, Kelley \& Hawk, 1969; Hawk \& Bolt, 1970). In the present experiments, doses of stilboestrol $(<0.5 \mathrm{mg} /$ day $)$ too low to prevent luteal regression, did not advance it. In the sheep, the antiluteolytic effect of oestradiol (Piper \& Foote, 1970) is associated with decreased progesterone production by the CL. This effect has not been seen by Denamur, Martinet \& Short (1970). They showed that twice-daily injections of oestradiol benzoate from Days 2 to 30 maintained the $\mathrm{CL}$, and that progesterone secretion on Day 20 was not significantly different from that on Day 12 of the cycle. These workers also proposed that the major effect of oestrogen in this species is antiluteolytic, and its luteotrophic action, exerted either directly, or indirectly through the pituitary, is very limited.

In the guinea-pig, the time of oestrogen administration is critically important with respect to its effect as a luteolytic or luteotrophic agent. The time course of the uterine luteolytic mechanism can only be shortened by experimental means within a few days of ovulation. By Day 4 or 5 , the sequence of events has been set and regression can no longer be accelerated although it can be abolished or delayed. The oestrogen-induced regression does not depend upon the age of the CL itself but upon uterine and pituitary factors. By mid-cycle, the capacity of the uterus and/or the pituitary to respond to oestrogen in such a way as to cause the swift regression of the CL has been abolished. From this time, oestrogen in sufficient doses overcomes the regressive action of the uterus and so prolongs the structural and functional life of the CL.

\section{AGKNOWLEDGMENTS}

We wish to thank the histology department for their preparation of many of the histological sections, and Mrs N. Ackland for skilled technical assistance. The work was performed during the tenure of a Wellcome Trust training scholarship to D.V.I. The gift of ECP from the Upjohn Co. is gratefully acknowledged.

\section{REFERENGES}

Bland, K. P. \& Donovan, B. T. (1968) Gonadal hormones and the regression of the corpus luteum in the guinea-pig. Nature, Lond. 220, 179.

Bland, K. P. \& Donovan, B. T. (1970) Oestrogen and progesterone and the function of the corpora lutea in the guinea-pig. F. Endocr. 47, 225.

Blatchley, F. R. \& Donovan, B. T. (1969) Luteolytic effect of prostaglandin in the guinea-pig. Nature, Lond. 221, 1065. 
Blatchley, F. R., Donovan, B. T., Poyser, N. L., Horton, E. W., Thompson, G. J. \& Los, M. (1971) Identification of prostaglandin $\mathrm{F}-2 \alpha$ in the utero-ovarian blood after treatment with oestrogen. Nature, Lond. 230, 243.

Challis, J. R. G., Heap, R. B. \& Illingworth, D. V. (1971) Concentrations of oestrogen and progesterone in the plasma of non-pregnant, pregnant and lactating guinea-pigs. F. Endocr. 51, 333.

Ghoudary, J. B. \& Greenwald, G. S. (1968) Luteolytic effect of oestrogen on the corpus luteum of the cyclic guinea-pig. F. Reprod. Fert. 16, 333.

Ghoudary, J. B. \& Greenwald, G. S. (1969) Reversal by gonadotrophins of the luteolytic effect of oestrogen in the cyclic guinea-pig. 7. Reprod. Fert. 19, 503.

Ghu, J. P., Lee, G. G. \& You, S. S. (1945) Functional relation between the uterus and the corpus luteum. F. Endocr. 4, 392.

Denamur, R., Martinet, J. \& Short, R. V. (1970) Mode of action of oestrogen in maintaining the functional life of corpora lutea in sheep. F. Reprod. Fert. 23, 109.

Denamur, R. \& Mauléon, P. (1963) Contrôle endocrine de la persistance du corps jaune chez les ovins. C. r. hebd. Séanc. Acad. Sci., Paris, 257, 527.

du Mesnil du Bursson, F. (1967) Contrôle du maintien du corps jaune de la truie. Archs Anat. microsc. Morph. exp. 56, 358.

Feder, H. H., Resko, J. A. \& Goy, R. W. (1968) Progesterone concentration in the arterial plasma of guinea-pigs during the oestrous cycle. F. Endocr. 40, 505.

GARDNER, M. L., First, N. L. \& GASIDA, L. E. (1963) Effect of oestrogen on corpus luteum maintenance in gilts. F. Anim. Sci. 22, 132.

GREeNWALD, G. S. (1967) Luteotropic complex of the hamster. Endocrinology, 80, 118.

HAwK, H. W. \& BoLT, D. J. (1970) Luteolytic effect of estradiol-17 $\beta$ when administered after mid-cycle in the ewe. Biol. Reprod. 2, 275.

Heap, R. B., Perry, J. S. \& Rowlands, I. W. (1967) Gorpus luteum function in the guinea-pig: arterial and luteal progesterone levels and the effects of hysterectomy and hypophysectomy. $\mathcal{F}$. Reprod. Fert. 13, 537.

IlLINGWORTH, D. V. (1969) Luteolytic and luteotrophic effects of oestrogen in the guinea-pig. $\mathcal{F}$. Reprod. Fert. 18, 548.

ILLINGWORTH, D. V. (1971) The regulation of luteal function in the guinea-pig. Ph.D. thesis, University of Cambridge.

Iltingworth, D. V., Heap, R. B. \& Perry, J. S. (1970) Changes in the metabolic clearance rate of progesterone in the guinea-pig. F. Endocr. 48, 409.

IllingWORTH, D. V. \& PERRY, J. S. (197I) The effect of hypophysial stalk-section on the corpus luteum of the guinea-pig. 7. Endocr. 50, 625.

McPhail, M. K. \& Parkes, A. S. (1933) The adaptation of parapharyngeal hypophysectomy to the guinea-pig and the hedgehog. Proc. R. Soc. B, 114, 10.

Nelson, W. O. (1935) Gonad hormone effects in normal, spayed and hypophysectomized rats. Anat. Rec. 64, Suppl. 1, Abstr. no. 54.

NishiKaWA, Y. \& WAmE, Y. (1958) Effect of stilboestrol injection at the corpus luteum stage in the sow with special reference to the long maintenance of corpora lutea. Bull. natn. Inst. agric. Sci., Tokyo, (Series G), 14, 1.

Perry, J. S. \& Rowlands, I. W. (1962) The effect of hypophysectomy on the ovarian cycle of the guinea-pig. F. Endocr. 25, v.

Piper, E. L. \& Foote, W. C. (1965) A luteotrophic effect of estradiol in the ewe. F. Anim. Sci. 24, 927.

Piper, E. L. \& Foote, W. C. (1970) The effect of $17 \beta$-estradiol on corpus luteum function in the sheep. Biol. Reprod. 2, 48.

Rowlands, I. W. (1961) Effect of hysterectomy at different stages in the life cycle of the corpus luteum in the guinea-pig. F. Reprod. Fert. 2, 341.

Rowlands, I. W. \& SHort, R. V. (1959) The progesterone content of the guinea-pig corpus luteum during the reproductive cycle and after hysterectomy. F. Endocr. 19,81.

Stormshak, F., KeLLEY, H. E. \& HAWK, H. W. (1969) Suppression of ovine luteal function by $17 \beta$ estradiol. F. Anim. Sci. 29, 476. 